\title{
Operational Risk, Translation, and Globalization
}

\author{
Barbara Czarniawska
}

ABSTRACT

\begin{abstract}
This paper compares a translation of a global (more specifically, European) regulation into two local contexts, setting this process in a broader context of the all-pervading risk management. The two countries are Sweden and Poland, both relatively untouched by the current financial crisis, and the regulation is Basel II Accord. In both countries, the translation is shaped by the past history, and the present circumstances. The results show that, in spite of local differences, there is a common belief in quantification of risks as the main remedy and therefore the main way of managing them. Abstract and vague formulations, combined with sophisticated calculation techniques, win over the complications of actual practices. The role of researchers in this process is also examined. A study illustrates also the advantages of translation theory versus diffusion theory of spreading of ideas.
\end{abstract}

KEY WORDS: $\quad$ translation, diffusion, globalization, operational risk, risk management

JEL Classification: M48

1 University of Gothenburg, Sweden

In 1956, in a book entitled Bourgeois Morality (English version published in 1986), Polish sociologist Maria Ossowska (1896-1974) described the historical development of a bourgeois morality. The description ended in contemporary Poland, a newly socialist country, but already past the horrors of Stalin's regime. One of her last chapters included the analysis of a brochure issued by the Polish Saving Bank (PKO) in 1948. A product of the new socialist regime, it revealed to Ossowska's critical eye strong sediments of the capitalist past ("For the sociologist, it is intriguing to see the detritus of the past continuing by force of inertia into the present", [Ossowska, 1986, p. 123]). The title of the brochure, "Industry and frugality", alluded - probably inadvertently - to Benjamin's Franklin's maxim "Be industrious and frugal, and you will be rich." The text of the brochure continued in the same spirit, and ended with

Corespondence concerning to this article should be addressed to: Barbara.Czarniawska@gri.gu.se what appeared to be an unintended allusion to a version of Aesop's fable about an ant and a grasshopper by Russian fabulist Ivan Krylov (1769-1844). In the fable, the ant was working and saving all summer long, while the grasshopper spent the summer singing, and now wanted to borrow money from the ant. "Go and dance then”, responded the ant. The Polish Saving Bank said almost the same thing, in verse form. Having compared the two texts, Ossowska (1986) hastened to assure readers that:

I am not concerned with taking the author of this pamphlet to task. After all, it is hardly surprising that any attempt to boost the virtue of thriftiness should have to tread well-worn paths, given the amount of propaganda devoted to this theme in bourgeois literature; though the climate of this propaganda should perhaps be recognized as alien in the new conditions, and in conflict (as in the fable of the ant and the cricket) with the ideals of socialism. (p. 125) 

copying machines do not produce copies identical to the original. Changes can be due to a faulty imitation, to a conscious adaptation to local circumstances, to the hidden hand of the past ("detritus" in Ossowska's terms - sediments in new institutional theory), but also because institutions are inscribed in machines (Joerges \& Czarniawska, 1998), and machines - especially computers - play a central role in glocalization processes.

The travel of the idea of "operational risk" is one of many that could well illustrate such a process (Power, 2007), even if this text focuses on only a small part of this travel; in fact, it can be seen as an addendum to Power's story of its earlier peregrinations. It also shows, as every translator knows, that even when the translation remains limited to a linguistic practice, translation is a destabilizing operation. It destabilizes the text under translation, which is taken from its original cultural context and fit onto another, even if the context is in itself cross-cultural, as in the case of global accords. Furthermore, the language into which the translation is made is destabilized, if ever so little, with every translation made - thus the need for the stabilizing role of dictionaries. One could claim that the text of the Basel II Accord was such a stabilizing dictionary (Power [2007], called it a "boundary object"). Yet a dictionary, no matter how perfect, does not guarantee the perfection of translation. It remains local, especially when words are being translated into practices.

\section{Operational risk: A Swedish translation}

When I began to question my Swedish colleagues about the connections between risk management and accounting, I was directed to a doctoral dissertation describing the history of public sector accounting in Sweden from the times of Gustaf Vasa to the present (Sandin, 1991). I consulted the work in question somewhat warily (in my early study of municipal reforms, I was told that they were initiated by the Vikings, which I believed for a while), and indeed, I found nothing on the topic. But at least two pieces of information captured my interest: the origin of Swedish accounting and the increased competence of accountants. Since the end of the 19th century, especially since the establishment of the Institute of Chartered Accountants in England and Wales, Swedish accounting and auditing were modeled after England's (Sandin, 1991, p. 43). During the same period there was a wave of frauds, fal- sifications, and embezzlements. The solution was seen to be an increase in the competence of accountants and auditors (the Swedish Audit Society was founded in 1899) and a strong emphasis on impartial and competent auditing. Two central auditing organizations were created at the beginning of the next century, one for private companies and the other for public administration organizations. The notion of "risk" was not mentioned. The elimination of frauds and misappropriation was to be achieved by a stronger control: a retrospective rather than a prospective monitoring of economic activity.

A popular accounting textbook (four editions between 1983 and 1997) mentions "risk" on one page and defines it as a decision situation between complete certainty and complete uncertainty of its consequences. A situation is risky, then, when one knows the possible consequences of a given decision and their respective probabilities (G. Andersson, 1997, p. 38). Later in the text, two paragraphs were dedicated to "risk analysis" (pp. 195-196). Things have changed since 1983, however, in Sweden as elsewhere. A 1995 doctoral dissertation dedicated to risk and efficiency in interbank payment systems (M. Andersson, 1995) contained a simulation of system risk in payments. Operational risk was seen as consisting of administrative risk and risk of fraud, and was commented upon in two half pages. But it was clear that risk management was becoming a central issue in financial institutions. An explosion of the concept transformed this local, US finance (or military) invention into a global trait (Power, 2004).

As commonly claimed, the problematic liquidation of a German bank in 1974 required that the G10 nations form the Basel Committee on Banking Supervision, which reached its first accord in 1988: the so-called Basel I. Much attention was paid there to the notion of credit risk, soon to be complemented by market risk, and then, in Basel II (2004), by operational risk It has been argued that such events as 9/11 and rogue trading at Société Générale, Barings, Allied Irish Banks (AIB), and National Australia Bank convinced the committee that risk management extends beyond market and credit risk.

Indeed, when the translation of ideas into actions is well advanced, the actors involved feel a need to mythologize by dramatizing origins. It may well be that, in 

swers puzzled him. He expected them to talk about "risk measurement, as described in leading [read 'mainstream', BC] scientific journals and in textbooks (...) Instead, the interviewees talked much more about risks that they could not measure" (Wahlström, 2009a, p. 291). Indeed, senior bank managers agreed that the greatest risk areas are those that defy quantified measurement, and pointed out that their most challenging task is to solve unanticipated problems. This second statement corresponds well to other studies of risk, in that it highlights the importance of "well-practiced improvisation" (Czarniawska, 2009). Although Wahlström's study was conducted in 2001, the article was written during the financial crisis of 2007 to 2010 , and he therefore concluded that risk measurement could create a false sense of safety, whereas a financial crisis can drastically change perceptions of what is the greatest threat. In this he agreed with Broadbent et al. (2008), who suggested that risk measurement could silence other risk assessments.

After the Basel II Accord was accepted, Wahlström returned to the four banks and conducted a new series of interviews. As before, opinions were divided into positive and negative, and as before, there was general support for Basel II. The positive opinions stressed the concordance of suggestions in the accord and actual banking practices (which may partly explain the tendency among Swedish organizations to implement the EU's and other international regulations well in advance; see Jacobsson, [1993]). The interviewees were also pleased by the fact that the accord permitted the banks to use their own measurement models, whereas the requirement for a measurement (not an assessment) of risks imposed a desirable uniformity on the banks. The criticisms revealed large gaps among the groups, however: managers with operational functions (usually older) and staff specialists in risk management (usually younger, with higher levels of education). The staff people, not surprisingly, thought all was well with operational risk measurement, whereas the operational people took a relatively critical view of the younger group, claiming a fissure in "our risk organization, with its $\mathrm{PhDs}$ and statisticians on the one side, and the managers who run the bank on the other". As one operational manager said, risk management "forms its own tradition in the theoretical world and at the universities. And soon there will be just three people in each bank who really understand the rules and can explain them" (Wahlström, 2009b, p. 61). Managers involved in running the operations noted that implementation of Basel II was costly (indeed, there are many IT companies that started to specialize in appropriate systems and software), but, more importantly, given the abstractness of Basel II, its relationship to reality is doubtful. Additionally, they saw Basel II as supporting a tendency toward centralization, which the more decentralized banks saw as a threat. As always, when ideas are translated into practices, they involve people and objects, identities, and computers.

The critics were well aware of the need for local translations. They pointed out that the accord itself was vague, but was considerably clarified when the Swedish Financial Supervisory Authority introduced its interpretation, based on a dialogue with the banks. As one CFO said, however, "We are afraid that the Swedish Supervisory Authority will interpret the regulation more strictly than the supervisory authorities in other countries. So we are afraid that there may be competitive disadvantages for Swedish banks with non-Swedish banks, including those with branches here in Sweden" (Wahlström, 2009b, p. 63).

So now I inspect another local translation - this time in Poland.

\section{Operational risk: A Polish translation}

For historical background, it is not necessary to return to the time of Gustaf Vasa or even to the time of Sigismund Vasa, a joint king of Poland and Sweden. The relevant history of Polish accounting starts in 1989, but until 1995 the transformed economy faced so many tasks and challenges that accounting served only as a basis for tax calculations and national statistics. The Bill of 1995 changed this situation, by emphasizing the role of financial accounting and requiring the creation of jobs responsible for external reporting, while separating tax law and law regulating financial statements. The modernization of accounting principles in 2002 further widened the gap, as did the introduction of the International Accounting Standards of 2005. Coping with these often-contradictory demands resulted in almost complete neglect of management accounting. It was not until the 2007 tax reform that the idea of an integrated accountancy model came to the fore, together with the promise of new IT systems and soft- 

contained in Sound Practices for the Management and Supervision of Operational Risk (Basel Committee on Banking Supervision, 2003). The article ends with an expression of the hope that these principles will guide Polish banks in the years ahead (Lewandowski, 2004). "Sound practices" have been rendered in Polish as "Best Practices".

After the 2007 tax reform and the Banking Supervision Committee (since then incorporated into Financial Supervision Committee) presented its interpretation of Basel II (I was unable to establish if it happened in a dialogue with the banks, as it had in Sweden), Bancarewicz (2007) wrote an article that she began by quoting an assessment of risk (25-30\% operational risk, $65-70 \%$ credit risk, and $10 \%$ market risk). The original article by Lenczewski, Martin and Niedziółka (2005) refers only to "research results", however, without specifying who conducted this research or where. Bancarewicz (2007) quoted the same percentages of causes as Gospodarowicz (2009) did in his chapter, but increased their visibility by presenting them graphically. The main part of the article, to quote its English abstract, "shows relevant difficulties and challenges that a bank may come across while collecting loss data and modeling operational risk" (Bancarewicz, 2007, p. 96). The analysis is purely speculative; in two places unspecified "other European banks" are mentioned.

Lenczewski Martin and Niedziółka’s (2005) article presents some research results, but primarily speculations and assessment, as their study was done immediately after Basel II and before the interpretation by Banking Supervision Committee. They predicted some of the same problems as Wahlström did, albeit some in the opposite direction. Different local translations may cause problems for international banks in Poland, not the other way around (although it is not spelled out that Polish interpretations are likely more tolerant). The classification of events included in operational risk may be a problem: the same events can be classified as market and operational risk, they can be wrongly monitored, and their consequences may be difficult to ascribe to an appropriate category. And, as in Sweden, many speculations concern the impact of operational risk on the required level of regulatory capital; but, unlike in Sweden, the expectation was that the measuring of operational risk would raise rather than lower this level.
I have finally located in "Risk in accounting" an ambitious co-authored work edited by Anna Karmańska (2008) - a small study that can be compared to Wahlström's. The entire book has nine authors, runs for 535 pages, and can probably be characterized as a handbook. It has no assignments and cases like other textbooks typically do. The 17 chapters are primarily encyclopedic, although each begins with a motto borrowed from a philosopher, a novelist, or even Yogi Berra, and some contain hypothetical examples. There are 234 pages of lists, organized with the help of Arabic numbers, Roman numbers, capitals, low caps, bullets, and dashes; 141 pages contain tables, many with lists. Only 24 pages contain equations, and as many have graphs or figures.

The survey of interest to me was presented on the last four pages of the text, with questions addressed to four top-level managers, who were well acquainted with both financial accounting and management accounting procedures. They were shown a risk report form, constructed according to suggestions from the authors of the volume, in which risk was separated into several categories, relating primarily to market and credit risk. The first question to these four managers was whether or not such a report was needed for financial analysis. The general answer was "yes", with the specification that if the report were to be correct, it had to remain internal information, and it would be of more use to large and middle-sized companies than to small companies. The second question concerned the suggested structure of the report, which achieved disparate responses. Two of the managers liked it, one was uncertain, and the fourth thought that open questions invited politically correct answers, although the same person admitted that closed questions could be difficult to formulate. The question concerning possible arenas of use raised some anxiety about the report becoming obligatory; but three persons saw it as a useful source of managerial information. Asked if some parts of the report should be better developed, the respondents protested, which can probably be explained by their answer to the next question, in which they estimated the preparation as time- and effort-consuming, at least the first time around. In their opinion, such a report should be prepared by their finance department. When asked if they had competent personnel who could accomplish the task, the only manager from 
a large company answered positively, yet added immediately that someone that competent should be occupied with more creative tasks. The other three managers answered negatively, as they considered their companies too small to include such personnel, the lack of which would require a preparation time of between two months and two years. In addition, three of the mangers were convinced that if the report had an external function, it would be no doubt manipulated.

The editor ended the volume by emphasizing the complexity of risk reporting and suggesting that a great many empirical studies were needed in the future. The fact that the sample used for the survey has been so limited is easier to understand in the light of the fact that Cap Gemini failed to conduct "Basel II Survey" among Polish banks in 2004. The response rate was so low that it was impossible to draw any conclusions from their study. The reporter who wrote the article reporting this failure asked several top managers for reasons (Gamdzyk, 2004). Those from other industries suggested that banks did not have and still do not collect appropriate data, and that bank managers were afraid of spending money on uncertain investments. Indeed, the bank representatives suspected IT companies of trying to make quick money on new systems and software, and indicated that the Polish banks are still relatively poor compared to other European equivalents. Thus they were unwilling to spend money on fulfilling requirements that, in 2004, were still far from well specified.

Before moving to a comparison of the two translations, I am presenting yet another case of accounting for risk, which I encountered by chance when collecting materials for the Polish translation of operational risks.

\section{Central Risk Register: Innovation or imitation?}

In 2008, the Polish vice-minister of finance told a journalist that the ministry was working, for the second year in row, on the creation of a Central Risk Register for the use of Customs Services. The Superior Chamber of Control approved the idea. Regional risk registers were to be included in a central register, which would be the basis of a strategic plan of control exercised by Customs, later translated into tactical control plans correlated with regional registers. Indeed, since 2007, the website of Customs Services and many other economic websites contained an appeal to companies and industry associations, "to help Customs to create their Central Risk Register". An official letter from the Ministry of Finance contained the same initial formulation every year:

In order to optimize the efforts, means and costs of operations, the Customs Service is obliged to focus inspection activities on the high-risk areas, so that legitimate trade, which does not cause the danger of budget losses, violations of law, and other kinds of threats to the national economy and society as a whole, could proceed with Service's minimal interference. Currently, the Customs Service is working to identify the most serious threats in particular risk areas (Ministry of Finance, 10 September 2009, my translation, BC).

The letter was addressed to 22 industry associations in Poland and, as indicated previously, was reprinted in part in various appeals on relevant websites. It contained two attachments in Excel format: Risk Profile and Risk Register.

The Risk Profile table contained 9 columns, as follows:

1. A detailed description of threat, depicting mechanisms leading to emergence of irregularity

2. Tariff, trade or conventional name of the goods

3. Incorrect code according to the EU Customs Tariff

4. Correct code according to the EU Customs Tariff

5. False country of origin, name or symbol of goods origin (several countries can be named)

6. Actual country of origin, name or symbol of goods origin

7. Name or symbol of the country of import or export

8. Additional information of potential use in control activities

9. Risk assessment on a scale 1 (low risk), 2 (medium risk), 3 (high risk).

The Risk Register table ran for 9 pages, of which I am quoting only one excerpt, together with introductory rows and final instructions. 


\begin{tabular}{ll|l|l|l}
\hline No. $\quad$ RISK AREAS & $\begin{array}{l}\text { POTENTIAL AND ACTUAL } \\
\text { THREATS/LACK OF } \\
\text { RECOGNIZED THREATS } \\
\text { (short description of } \\
\text { types of risk) }\end{array}$ & $\begin{array}{l}\text { GRADE (assessment) } \\
\text { OF RISK: } \\
\text { - probability -conse- } \\
\text { quences }\end{array}$ & $\begin{array}{l}\text { RISK LEVEL } \\
\text { I-III }\end{array}$ \\
\hline 1.1. $\quad$ Tariff classification & & & \\
1.2. $\quad$ Preferential origin & & & \\
1.3. $\quad$ Nonpreferential origin & & & \\
1.4. Customs value & & & \\
1.5. Goods customs status & & & \\
\hline
\end{tabular}

(...)

\section{AREAS RELATED TO HEALTH PROTECTION AND PUBLIC SAFETY}

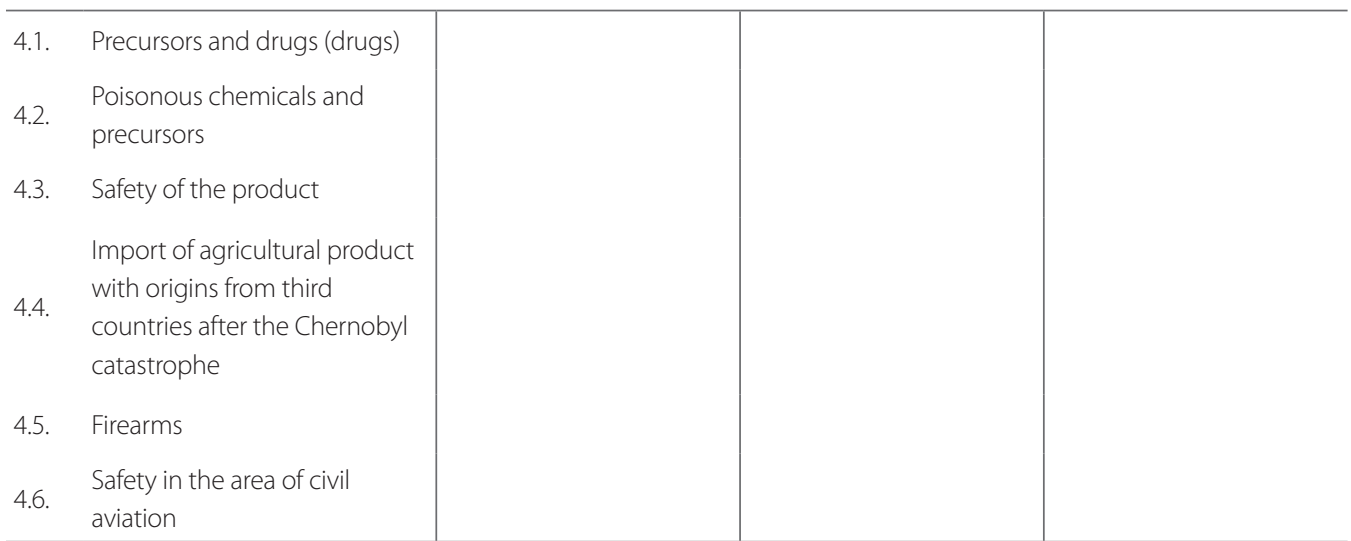

Grade (assessment) of risk on a scale from 1 to 5

Risk level (final assessment, e.g. R = probability + consequences; level I = low 2-4, level II = medium 5-7, level III = high 8-10).

As a result of the Central Risk Register compiled in 2009 , it was decided that Customs Services would concentrate its activities during 2010 on "tobacco products"; "engine fuels"; "alcoholic drinks"; "tariff classification"; and, a requirement of the Department of Customs and Excise, on "games of hazard". The ministry also claimed that the effectiveness of customs control doubled in 2008 compared to 2007, and doubled again in 2009 (onet.business, 24 February 2010).

There were at least two aspects of this ambitious project that attracted my attention. There was no mention in the materials I found of the origins of the idea behind Central Risk Register. Was it a Polish invention? If so, did it not reveal the same phenomenon described by Ossowska: the habit of centralization from the previous regime projected onto the new regime?

To be on the safe side, I initiated a new search, and it soon brought results. In 2004 the UK government's National Audit Office (NAO) issued a report by the Comptroller and Auditor General, entitled Managing Risks to Improve Public Services. It contained "case studies", one of which concerned Her Majesty's Customs and Excise. This is what the Customs and Excise did:

Assessment of risks is the responsibility of the relevant risk owner. A standardised risk evaluation methodology is used across the Department. The Management Committee reviews all 'red' risks from the central risk register on a monthly basis and 'amber/red' risks at least quarterly. Each quarter, an exercise is commissioned to update 
the central risk register in full. These timescales are repeated for all other lower level risk registers throughout the Department (NAO, 2004, p. 3).

The comparison strengthened my second cause for bewilderment: unlike its UK counterpart, the Polish Ministry asked the objects of Customs Services their clients, as it were - to identify and describe risks. Was it, as my Polish colleagues suggested, because the control should actually concern Customs Services, which was perceived as being corrupt and unfair? Or was it done on the assumption that honest entrepreneurs, and especially industry associations, would be those most motivated to indicate risk areas correctly? Whichever assumption is correct, one could ask how many unexpected results came from this time- and effort-consuming reporting of risks. Any person on the street would likely suggest the same risk areas produced by the Central Register.

There was yet another difference between the Polish and UK initiative. The UK's NAO commissioned case studies of risk management in five government departments and four private companies with global operations. The case studies were conducted in the following way:

In departments, interviews were carried out with
key senior managers responsible for the areas of
work concerned. These were supplemented by
desk research, material gathered from our sur-
vey of departments, and by two focus groups for
each study designed to gather views and experi-
ences of applying risk management from wider
staff involved in the delivery network. The focus
groups were mainly of staff at middle and senior
management levels. (...) For our private sector
comparisons, interviews took place with senior
managers of the company with responsibility for
risk management (NAO, 2004, p. 1).

The publishing of the results was seen as a way of encouraging other public and private sector organizations to introduce similar measures: "While the examples we give of risk management in operation are specific, they draw on risk management principles and practices that can be applied more widely" (NAO, 2004, p. 1). No such initiative could be located in Poland, neither in the case of the Central Risk Register nor in the case of operational risk measurements. Textbooks and journal articles offer a linguistic translation and an explication of official documents, now and then quoting survey results from other countries. They employ the same "technical way without discussion of potential advantages and disadvantages" that, according to Wahlström (2006), explained the persuasiveness of Basel II. Opinions from practice arise, if at all, in media interviews. I comment on Wahlström's observation further in the next section.

\section{Translations compared}

The picture of the introduction of Basel II in Sweden confirms many similar observations made on various previous occasions. In describing how Sweden followed EU rules even before joining the Community:

Swedish administration had often imported management ideas. Lübeck ran the City of Stockholm as an enterprise. German Conrad von Pyhy saw to it that Gustaf Vasa had the most modern accounting system of the time at his disposal, so that taxes could be properly collected. We allowed the most dedicated capitalists we knew, the Dutch, to built and start Gothenburg. The Swedish state and municipal administration often drew inspiration from the outside. These ideas were then modified in encounter with local traditions (Jacobsson, 1993, p. 113; my translation, BC).

Indeed, studies from various times and of various areas show a similar picture: the Swedish public administration is always au courant with the newest fashions in what was previously called administration, and is now called management. As a "negotiated economy" (Hernes, 1978), it was and is in constant dialogue with the private sector. For many years it was a global "fashion leader", proudly presenting "the Swedish model" of a welfare state to visitors, it admitted its demise (Czarniawska, 1996) and started sending envoys to New Zealand, the Mecca of New Public Management. Swedish city management is alert to all city fashions: fast trams, IT cities, and most recently, the Ferris wheel. But, as Jacobsson pointed out, new ideas are transformed in encounters with local customs, in a pragmatic way - not least because the voices of practitioners are seriously considered. 
It is therefore justifiable to apply this frame of reference to the reaction of the Swedish banks to Basel II. They were eager to implement it, being satisfied with the fact that the required procedures corresponded to their own. The Swedish Financial Supervision Authority interpreted the abstract requirements in a dialogue with the banks. The main split is between the older and the younger generations, corresponding to the split between operational and staff duties shown in Wahlström's (2009b) research. The older, operational managers are skeptical, especially about the cost of new IT systems and the correspondence between abstract models and measurements derived from them; the younger, staff people are enthusiastic.

No such gap can be found in Poland, for two reasons. Because of the dramatic change of the political regime and the consequent changes in running the economy, there are no "old, experienced bankers". Furthermore, one may suspect a common positive perception of abstract models and numeric calculations across generations, due to an anti-pragmatic attitude, which I called "merciless idealism" in my city study (Czarniawska, 2002, p. 119). One of its elements is "trust in numbers" (Porter [1995]; but also "trust in models"; Power [2007, p. 120]), albeit with a local twist. Numbers were commonly manipulated during the socialist regime, but faith in "correct numbers" remains - the correct numbers guaranteed by a non-ideological science.

Rottenburg (1994) described a similar attitude in managers from East Germany at the time of unification - an attitude that he called "socialist monism" - "that definitions of reality are either ideological constructs and, therefore, false, or they correspond to reality and are, therefore, valid" (p. 89). The pragmatist conviction that words and numbers can be compared only with other words and other numbers (Rorty, 1980) did not gain any ground; the correspondence theory of truth rules unquestioned. This attitude is not limited to Poland, of course; indeed Power (2007) spoke of "calculative idealists" (p. 120). In Poland their dominance seems to be absolute.

Another observation concerns the fact that although both Sweden and Poland largely follow the UK example in accounting for risk management, the imitation stops at dialogue with practitioners. There are no traces of any official dialogue between law enforcers and practitioners in Poland, but there are also no studies of practice, apart from the limited survey described here. There are, of course, serious differences between the case studies commissioned by the House of Commons and those conducted by Wahlström, but they are expected differences - those between official investigations and scholarly research. Furthermore, even in Sweden, the media are often a necessary mediator among researchers, and politicians and officials. But the contacts and mediations do happen, and researchers are often asked to join or lead official investigations.

Between 1972 and1980, I served as a methodological consultant and researcher in a research program "Managing enterprises - participants in the consumer goods market" (Beksiak, 1978), in which an extensive field study of actual management practices was conducted, probably for the first time. Field studies in Poland have not vanished, for Polish and foreign researchers are conducting organizational ethnographies (Kostera, 2011). But such studies, being unquantifiable, are seen as being of no use in an official context. "Calculative pragmatists" (Power, 2007, p. 121) seems to be an empty category, or at least a not-yet-located group. The label is a good fit with the older operation managers interviewed by Wahlström. ${ }^{\text {? }}$

Sweden has a long tradition of field studies and studies of practices, and in this aspect does not have to imitate UK. A critical and sociological take on accounting, however, is clearly a UK influence. Yet I am not sure if Polish accounting scholars are at all aware that accounting can be a social science ${ }^{8}$ (neither Accounting, Organizations and Society or Critical Perspectives on Accounting are to be found in Warsaw University Library). As I see it, "socialist monism" has been replaced in the official discourse by "capitalist monism"; the top-to-bottom" approach in centrally steered initiatives remains, as does the role of the researchers as translators of top leaders' intentions to the wider public.

However, this analysis must not be read as an eulogy for the Swedish way of translating global trends and a critique of the Polish ways of doing so. Some aspects of the Swedish translation are no doubt positive - the dialogue of authorities with practitioners and the problematizing attitude of researchers. Some aspects of the Polish translation are easy to understand in the light of the past and present economic situation. 
However, both countries set to translate global directives without, it seems, ever asking a question whether they make sense or not. What if operational risk is but a Snark?

Just the place for a Snark! I have said it thrice: What I tell you three times is true." (...) "Taking Three as the subject to reason about A convenient number to state We add Seven, and Ten, and then multiply out By One Thousand diminished by Eight. "The result we proceed to divide, as you see, By Nine Hundred and Ninety Two: Then subtract Seventeen, and the answer must be Exactly and perfectly true.

"The method employed I would gladly explain, While I have it so clear in my head, If I had but the time and you had but the brain -

The Hunting of the Snark, by Lewis Carroll

\section{References}

Andersson, G. (1983/1997) Kalkyler som beslutsunderlag. Lund: Studentlitteratur.

Andersson, M. (1995) Kontroll av bankernas betalningssystem. Stockholm: Nerenius \& Santérus Förlag.

Bancarewicz, G. (2007) AMA - selected issues in the areas of operational risk data and operational risk modeling. Bank i Kredyt, August-September: 96-105.

Beksiak, J. (ed.) (1978) Zarządzanie przedsiębiorstwami - uczestnikami rynku dóbr konsumpcyjnych. [Corporate governance - market participants, consumer goods]. Warszawa: PWN.

Broadbent, J., Gill, J., \& Laughlin, R. (2008) Identifying and controlling risk: the problem of uncertainty in the private finance initiative in the UK's national health service. Critical Perspectives on Accounting, 19(1), 40-78.

Brown, S. D. (2002) Michel Serres. Science, translation and the logic of parasite. Theory, Culture \& Society, 19(3), 1-27.

Callon, M. (1980) Struggles to define what is problematic and what is not: The socio-logic of translation. In: C. K. Knorr, R. Krohn, \& R. Whitley (eds.) The social process of scientific investigation: Sociology of the sciences, Vol. IV. Dordrecht: D. Reidel.
Carter, C. (2008) A curiously British story: Foucault goes to business schools. International Studies of Management \& Organization, 38(1), 13-29.

Czarniawska, B. (1996) Changing times and accounts: tales from an organization field. In: R. Munro, \& J. Mouritsen (eds.) Accountability. Power, ethos and the technologies of managing. (pp. 308-328) London: Thomson Business Press.

Czarniawska, B. (2002) A tale of three cities, or glocalization of city management. Oxford: Oxford University Press.

Czarniawska, B. (2009) Conclusions: plans or wellpracticed improvisations? In: B. Czarniawska (ed.) Organizing in the face of risk and threat. (pp. 166196). Cheltenham: Edward Elgar.

Czarniawska, B., \& Sevón, G. (1996) Introduction. In: B. Czarniawska, and G. Sevón (eds.) Translating organizational change. (pp. 1-12). Berlin: de Gruyter.

Gamdzyk, P. (2004) Daleko do Bazylei. [Far from Basel]. ComputerWorld, 30 August, Retrieved from http://www.computerworld.pl/artykuly/43665/ Daleko.do.Bazylei.html (accessed 2011-10-16).

Gospodarowicz, A. (2009) Ryzyko operacyjne w banku. In: K. Jajuga (ed.) Zarządzanie ryzykiem. (pp. 269-284) Warszawa: PWN.

Hamilton, G. (1985/1996) Risk management 2000. Lund: Studentlitteratur.

Hernes, G. (1978) Forhandlingsøkonomi og blandingsadministrasjon. [Negotiated economy and mixed administration] Bergen: Universitetetsforlag.

Jacobsson, B. (1993) Europeisering av förvaltningen. [Europeanization of public administration] Statsvetenskaplig Tidskrift, 96(2), 113-137.

Joerges, B., \& Czarniawska, B. (1998) The question of technology, or how organizations inscribe the world. Organization Studies, 19(3), 363-385.

Karmańska, A. (ed.) (2008) Ryzyko w rachunkowości. [The risk in accounting] Warszawa: Difin.

Kostera, M. (ed.) (2011) Etnografia organizacji: Badania polskich firm i instytucji. [Ethnography of organization: Research of Polish companies and institutions] Sopot: GWP.

Kucharski, A., \& Kucharska, N. (2010) Czy wdrożenie zintegrowanego modelu rachunkowości może ograniczyć ryzyko podatkowe? [Is the implementation of integrated accounting model can reduce 
the tax risk?] 1 September, Retrieved from http:// www.parkiet.com/artykul/964087.html, accessed 2011-10-16.

Latour, B. (1986) The powers of association. In: J. Law (ed.) Power, action and belief. (pp. 261-277). London: Routledge and Kegan Paul.

Latour, B. (1993) We have never been modern. Cambridge, MA: Harvard University Press.

Lenczewski M., C., \& Niedziółka, P. (2005) Kwantyfikacja ryzyka operacyjnego $\mathrm{w}$ banku oraz jego wpływ na wymóg kapitałowy. [Quantification of operational risk in the bank and its impact on capital requirement]. Bank i Kredyt, May, 28-41.

Lewandowski, D. (2001) Ryzyko operacyjne w działalności banków - nowe wyzwania, pilna konieczność zarządzania. [Operational risk in banks new challenges, the urgent need to manage]. Bank i Kredyt, May, 29-35.

Lewandowski, D. (2004) Ryzyko operacyjne w bankach - zarządzanie i audyt w świetle wymagań Bazylejskiego Komitetu ds. Nadzoru Bankowego. [Operational risk in banks - management and audit in light of the requirements of the Basel Committee on Banking Supervision]. Bank i Kredyt, April, 48-55.

NAO (2004) Managing risks to improve public services. Case studies. Report by the Comptroller and Auditor General. HC 1078-II Session 2003-2004: 22 October. London: The Stationery Office.

Nowak, E. (2010) Rachunkowość w zarządzaniu ryzykiem $w$ przedsiębiorstwie. [Accounting for risk management in the enterprise]. Warszawa: PWE.

onet.business (2010) MF: w 2010 pod lupę celników trafi m.in. tytoń, alkohol, paliwa. 24 February, Retrieved from http://podatki.onet.pl/ mf-w-2010-r-pod-lupe-celnikow-trafi-min-tytonalko,19925,3182382,1,agencyjne-detal (accessed 2011-10-16).

Ossowska, M. (1956) Moralność mieszczańska. [Bourgeois morality] Warszawa: PWN. English version: Bourgeois morality (1986) London: Routledge and Kegan Paul.

Power, M. (2004) The risk management of everything. London: Demos.

Power, M. (2007) Organized uncertainty. Designing a world of risk management. Oxford: Oxford University Press.
Robertson, R. (1992) Globalization. Social theory and global culture. London: Sage.

Robertson, R. (1995) Glocalization: Time-space and homogeneity-heterogeneity. In: M. Featherstone \& S. Lash (eds.) Global modernities. (pp. 25-44) London: Sage.

Robson, K. (1991) On the arenas of accounting change: The process of translation. Accounting, Organizations and Society, 16(5/6), 547-570.

Rogers, E. (1962): Diffusion of innovation. New York: Free Press.

Rorty, R. (1980) Philosophy as the mirror of nature. Oxford: Basil Blackwell.

Rottenburg, R. (1994) From socialist realism to postmodern ambiguity. Industrial \& Environmental Crisis Quarterly, 8(1), 71-91.

Sahlins, M. (2001) "Sentimental pessimism" and ethnographic experience or, why culture is not a disappearing “object”. In: L. Daston (ed.) Biographies of scientific objects. (pp. 178-202) Chicago, IL: University of Chicago Press.

Sandin, A. (1991) Statlig redovisning i förändring. Från Gustaf Vasa till nutid. [Governmental accounting in transition. From Gustavus Vasa to the present]. Gothenburg: Gothenburg School of Economics and Commercial Law.

Sobańska, I. (ed.) (2010) Rachunkowość zarządcza. Podejście operacyjne i strategiczne. [Management accounting. Operational and strategic approach]. Warszawa: Wydawnictwo C.H. Beck.

Tarde, G. (1890/1903): The laws of imitation. New York: Henry Holt.

Wahlström, G. (2006) Worrying but accepting new measurements: the case of Swedish bankers and operational risk. Critical Perspectives on Accounting, 17, 493-522.

Wahlström, G. (2009a) Risk in practice - senior bank managers at work. International Journal of Critical Accounting, 1(3), 287-305.

Wahlström, G. (2009b) Risk management versus operational action: Basel II in a Swedish context. Management Accounting Research, 20, 53-68.

\section{Endnotes}

1 A brief but instructive introduction to Serres' work can be found in Steven D. Brown (2002).

2 In this it differs from the interpretation of Keith 
Robson, to whom translation is "the process through which often pre-existing accounting techniques, and their associated roles, are articulated discoursively" (Robson, 1991, p. 550).

3 The categories of operational risk listed by Basel II: Internal Fraud - misappropriation of assets, tax evasion, intentional mismarking of positions, bribery

External Fraud - theft of information, hacking damage, third-party theft and forgery Employment Practices and Workplace Safety discrimination, workers compensation, employee health and safety

Clients, Products, \& Business Practice - market manipulation, antitrust, improper trade, product defects, fiduciary breaches, account churning

Damage to Physical Assets - natural disasters, terrorism, vandalism

Business Disruption \& Systems Failures - utility disruptions, software failures, hardware failures

Execution, Delivery, \& Process Management - data entry errors, accounting errors, failed mandatory reporting, negligent loss of client assets.

4 The managers' optimism concerning the role of operational risk measurement as protection against financial crisis was proven ungrounded by the latest events. I would predict that asked the same question today, the managers would still divide into two groups. Those who were positive would claim that more and better measurement of operational risk is needed and those who were negative would claim that their fears were founded.

5 By now, the employees are probably well trained in the popular use of a management technology called SWOT, which is supposed to disclose the strengths and weaknesses of an organization. The standard weakness thus revealed is a lack of resources, thereby turning a self-evaluation into a tactical move toward top management.

6 All translations from Polish are mine, BC.

7 Calculative pragmatists “.... are more sceptical about the role of numbers in managing operational risk (...) They typically regard them as attention-directive devices with no intrinsic claims to represent reality (...) They are more pluralistic about operational risk management, partly because they think capital should not be the sole foundation of risk management practice" (Power, 2007: 121).

8 In the spring of 2011, I taught a doctoral course at Warsaw School of Economics called "Social dimensions of enterprise". The students said that they found it interesting, but that they did not think it could be used in research on economic phenomena. 